\title{
“QUEM TEM RAZÃO, KANT OU STENDHAL?” UMA REFLEXÃO SOBRE A CRÍTICA DE NIETZSCHE À ESTÉTICA DE KANT*
}

\author{
João Constâncio ** \\ joaoconst@yahoo.com
}

RESUMO O artigo é uma reflexão sobre o modo como, na "Genealogia da Moral", Nietzsche repensa "o problema estético" a partir da oposição entre a concepção kantiana do belo como predicado de um juízo "desinteressado" e a concepção stendhaliana do belo como efeito de uma "cristalização" $e$ uma "promessa de felicidade". A chave do pensamento de Nietzsche neste contexto está no conceito de "embriaguez" (Rausch), por um lado, como termo-chave para designar a "pré-condição fisiológica" da arte, mas, por outro, como um processo de espiritualização dos instintos ou das pulsões que as interioriza e intensifica. Esta espiritualização distingue-se da contemplação desinteressada porque não nos des-afecta e porque é, em grande medida, uma espiritualização da sexualidade, mas não deixa, por isso, de implicar uma reavaliação dos valores e uma ampliação do horizonte do humano. É por isso que a arte pode ser pensada como um "contra-movimento" que afirma a vida e combate o "ideal ascético" e o "niilismo europeu".

Palavras-chave Arte, juízo estético, cristalização, espiritualização, niilismo.

* Todas as traduções são da responsabilidade do autor. No caso da "Genealogia da Moral", cita-se a tradução de José Justo, mas com modificações: NIETZSCHE, F. "Para a Genealogia da Moral". Lisboa: Relógio d'Água, 2000. Na citação de obras de Nietzsche, usam-se as abreviaturas da revista Cadernos Nietzsche.

** Departamento de Filosofia/ Faculdade de Ciências Sociais e Humanas/ Universidade Nova de Lisboa. Artigo recebido em 12/07/2013 e aprovado em 22/11/2013. 
ABSTRACT The present article is a reflection on the way how, in "Genealogy of Morals", Nietzsche rethinks "the aesthetic issue" based on the opposition between Kant's conception of beauty as a predicate of a "disinterested" judgment and the stendhaliana conception of beauty as the effect of a "crystallization" and a "promise of happiness". The key to the thought of Nietzsche's in this context resides on the concept of "intoxication" (Rausch) on the one hand, as a key-term to designate the "pre-physiological condition" of art, but on the other hand, as a process of spiritualisation of the instincts or of the drives, which internalizes and intensifies them. This spiritualization is distinguished from disinterested contemplation for it does not dis-affects us, and because it is by large a spiritualization of sexuality, without renouncing to imply a revaluation of the values and a widening on the horizon of the human. That is why art can be thought of as a "countermovement" that affirms life and fights the "ascetic ideal" and the "European nihilism".

Keywords Art, aesthetic judgment, crystallization, spiritualization, nihilism.

\section{I}

No capítulo 6 do Terceiro Ensaio da "Genealogia da Moral" - onde se trata da questão do "interesse" e da concepção kantiana e schopenhaueriana do juízo estético como um juízo "desinteressado" -, Nietzsche repensa "o problema estético" como uma oposição entre Kant e Stendhal (GM III 6). Segundo diz, uma das razões por que Kant (tal como, depois, Schopenhauer) pôde interpretar o juízo "isto é belo" como um juízo desinteressado foi o facto de ter pensado a arte e a experiência estética do ponto de vista do "espectador", e não sob a óptica da criação artística, i.e. não sob a óptica do artista:

[...] a única coisa que quero sublinhar é que Kant, como todos os filósofos, em vez de encarar o problema estético a partir das experiências do artista (do criador), conduziu a sua reflexão sobre a arte e o belo estritamente a partir do ponto de vista do 'espectador', e que, desse modo, sem se dar conta, introduziu o próprio 'espectador' dentro do conceito de 'belo'. Se ao menos os filósofos do belo conhecessem bem este 'espectador'...! Ou seja, se conhecessem nele uma experiência pessoal grande, um facto pessoal grande, uma enorme quantidade de vivências, de desejos, de surpresas, de encantamentos singulares e intensos, no plano do belo! Mas temo bem que tenha acontecido sempre o contrário: e assim, o que têm para nos dar são, desde o princípio, definições em que a falta de uma experiência pessoal com alguma subtileza reveste a forma do verme gordo que habita as regiões do erro radical, como 
acontece com a famosa definição kantiana do belo. 'Belo', diz Kant, 'é o que agrada desinteressadamente'. Desinteressadamente! Compare-se com esta definição uma outra, dada por um verdadeiro 'espectador' e artista, Stendhal, que a certa altura chama ao belo 'une promesse de bonheur'. Ao menos aqui recusa-se e elimina-se precisamente a única coisa que Kant destaca no estado estético: le désintéressement. Quem tem razão, Kant ou Stendhal? (GM III 6)

Se pensarmos o "espectador" como espectador interessado e se pensarmos o seu interesse no belo a partir da óptica do artista, i.e. da óptica da criação do belo, chegamos à definição do belo como "uma promessa de felicidade". O que significa esta ideia de uma "promessa de felicidade"?

A chave está obviamente no famoso conceito de "cristalização", criado por Stendhal:

Aquilo a que chamo cristalização é a operação do espírito que em tudo o que se lhe apresenta descobre que o objecto amado tem novas perfeições. [...]

Este fenómeno, a que me permito chamar cristalização, provém da natureza, que nos ordena que tenhamos prazer e faz subir o sangue para o cérebro com o sentimento de que os prazeres aumentam com as perfeições do objecto amado, e com a ideia: ela é minha. ${ }^{1}$

O "amor-paixão" depende fundamentalmente desta "operação do espírito" que descobre em todos os acontecimentos e circunstâncias (mesmo naquelas que, de outro modo, seriam consideradas negativas) sinais de novas perfeições do objecto amado. A sua intensidade depende não tanto da admiração, da esperança e da proximidade que geram a "primeira cristalização" quanto da dúvida e da distância, que resultam da "segunda cristalização". Nesta, o espírito oscila entre o "sim, ela ama-me" e o "será que ela me ama?", mas a imaginação forma um tal sentimento das "perfeições" do objecto amado, i.e. da sua beleza, que essa dúvida tem sempre como pano de fundo a certeza: "ela vai proporcionar-me prazeres que só ela em todo o mundo me pode proporcionar". ${ }^{2}$ É neste sentido que o belo é uma "promessa de felicidade": o belo só se manifesta num objecto que, de uma forma ou de outra, se tornou um "objecto amado", e só se manifesta nele na medida em que ele se constitui como "promessa", como signo de uma felicidade por vir, como um sinal de prazeres que se imagina só poderem vir a ser proporcionados por esse objectoamado (pelas suas supostas "perfeições"), e por nada mais.

1 Stendhal, 1980 (1822), p. 31 (capítulo II). A definição do belo como "promessa de felicidade" ocorre na página 59 desta edição, capítulo XVII.

2 Cf. Stendhal, 1980 (1822), pp. 30-33 (capítulo II). 
Stendhal é um dos poucos autores sobre os quais Nietzsche se pronuncia de forma sempre positiva, e poucos conceitos parecem ter despertado nele uma admiração tão incondicional como o de amour-passion. ${ }^{3}$ De facto, a interpretação do amor-paixão como cristalização tem imediatamente uma série de implicações anti-schopenhauerianas - e, em última análise, antiniilistas - que são particularmente apelativas para Nietzsche. Podemos, talvez, sistematizá-las da seguinte forma:

1. O conceito de cristalização faz depender a beleza do amor, até do amorpaixão, e está portanto nos antípodas da concepção do belo como objecto de uma contemplação desinteressada.

2. O conceito de cristalização permite pensar o belo artístico e a própria arte a partir da experiência do amor-paixão e do sentimento de que a mulher amada é bela. No fundo, identifica as duas experiências: do ponto de vista psicológico (ou "fisio-psicológico"), a arte é em tudo semelhante ao amorpaixão, o amor-paixão é em tudo semelhante à experiência da contemplação e da criação artísticas.

3. O conceito de cristalização permite pensar o desejo como uma forma de prazer: se o desejo é uma "falta", isso não implica, ao contrário do que sustenta Schopenhauer (e, por exemplo, a personagem Sócrates no "Górgias" de Platão), que o desejo seja "dor". Na própria dúvida e na distância, o apaixonado tem o mais intenso dos prazeres ao imaginar as "perfeições" do objecto amado e ao antecipar os prazeres únicos (ou a felicidade) que elas prometem. Quer na arte, quer no amor-paixão, o desejo já é prazer ou, na terminologia de Nietzsche, é em si mesmo uma forma de Rausch, de "embriaguez", "intoxicação", "êxtase".

4. O conceito de cristalização permite pensar o belo como uma projecção, no fundo como o efeito da representação das perfeições que a imaginação do apaixonado (ou, no caso da arte, a imaginação do artista primeiro, a imaginação do espectador depois) projecta no objecto amado. (Veremos adiante que o belo é para Nietzsche uma projecção no sentido de um antropomorfismo que projectamos nas coisas e que nos devolve uma imagem da nossa própria perfeição).

5. Na verdade, o conceito de cristalização antecipa a ideia de que a contemplação do espectador é um acto criativo e deve ser pensada do ponto de vista do artista como criador. Mesmo a "primeira cristalização" não resulta de uma percepção passiva, mas já de uma "operação do espírito" em que a 
imaginação está activa e, de forma espontânea e sem intenção consciente, não só destaca como aumenta determinadas propriedades do objecto amado - "cristaliza-as", transformando-as em "perfeições" deste objecto. No único passo em que Nietzsche usa o termo "cristalização" - uma nota póstuma de 1880-1881 -, põe em relevo precisamente este aspecto, perguntando-se se a cristalização implica uma determinada forma de mentira (o auto-engano) e de criação de erros: "Mas quando deixamos as nossas paixões crescer, com isso cresce também, como sabemos, a 'cristalização': ou seja, tornamo-nos desonestos e entregamo-nos livremente ao erro?" (KSA 9. 391, 8[40]).

6. Por fim, e na sequência do ponto anterior, o conceito de cristalização permite pensar um fenómeno que é crucial para Nietzsche, e que já referimos no capítulo 3: a "espiritualização" (Vergeistigung), "sublimação" (Sublimieren), ou "refinamento" (Verfeinerung) das pulsões, e em particular da pulsão sexual. O processo de surgimento do amor-paixão é um típico processo de espiritualização, quer nos casos em que principia apenas com um primeiro olhar, quer nos casos em que corresponde, por exemplo, a uma progressiva transformação de um "amor-prazer", de um "amor físico", ou de um "amor-vaidade". A espiritualização de uma pulsão, no sentido nietzschiano do termo, é algo totalmente diferente do que Schopenhauer descreve como a passagem do "interesse" ao "desinteresse" (à impessoalidade, imparcialidade e universalidade). A espiritualização nietzschiana é um processo de interiorização, e não de des-afectação. Uma pulsão torna-se mais "espiritual" quando é, por assim dizer, refeita por uma multiplicidade de actos de imaginação e conceptualização que a intensificam. Por um lado, a nossa relação com o objecto torna-se mais distante - pois é mediada por imagens e conceitos que se formam em novos afectos, bem como em novos sentimentos, volições e pensamentos conscientes -, mas, por outro, torna-se mais intensa, num certo sentido mais próxima - pois tudo acontece como se o espírito se estivesse a apropriar do objecto da pulsão, a "interiorizá-lo". O que de todo não acontece é que a pulsão seja temporária ou permanentemente erradicada (como supostamente acontece na passagem do "interesse" ao "desinteresse", bem como em certas concepções da "sublimação" do desejo). É ainda ela que é espiritualizada, são os seus afectos inconscientes e sentimentos conscientes que se intensificam e o seu objecto que é interiorizado. Pode, de facto, falarse aqui de uma intensificação do desejo - portanto do contrário do que seria a erradicação do desejo implicada na contemplação desinteressada.

Embora, como dissemos, Nietzsche só use o termo "cristalização" numa nota póstuma, são muitos os passos em que pensa a arte a partir do fenómeno da cristalização. Assim é, sobretudo, no "Crepúsculo dos Ídolos” e em diversas 
notas de 1887 e 1888, onde a "embriaguez" (Rausch) se torna o termo-chave para designar a "pré-condição fisiológica" (CI Incursões 8) da arte e de toda a criação e contemplação estética e artística. A embriaguez, defende Nietzsche, tem muitas formas (há, por exemplo, a embriaguez da festa, da competição, da vitória, dos narcóticos, da crueldade ou da vontade), mas a principal (a "mais antiga e mais originária") é a embriaguez da "excitação sexual" (CI Incursões 8). Em todas as suas formas, a embriaguez torna possível a arte porque é um "idealizar", é uma pulsão para "tornar perfeito", um processo "fisio-psicológico" de cristalização de perfeições:

O essencial na embriaguez é o sentimento de intensificação da força e do preenchimento. Com este sentimento damo-nos às coisas, obrigamo-las a tomaremnos, violentamo-las,- chama-se a este processo idealizar. Libertemo-nos aqui de um preconceito: o idealizar não consiste, como geralmente se crê, em subtrair ou eliminar o que é pequeno, o acessório. O decisivo é, antes, um tremendo pôr em destaque das características principais, de tal forma que as outras desaparecem. (CI Incursões 8)

Neste estado, o nosso preenchimento faz que tudo aumente: o que vemos, o que queremos, vêmo-lo inchado, repleto, forte, sobrecarregado de força. O ser humano que se encontra neste estado transforma as coisas, até que o seu poder se acha espelhado nelas,- até que elas se tornam reflexos da sua perfeição. Este ter de transformar em perfeito é - a arte. Mesmo tudo aquilo que o ser humano não é se torna, apesar disso, um prazer que ele tem consigo mesmo; na arte, o ser humano desfruta de si mesmo como perfeição. (CI Incursões 9)

Aqui, torna-se clara pelo menos uma parte do que Nietzsche quer dizer quando critica as teorias estéticas que pensam a arte do ponto de vista do espectador e não do artista. Só se pensarmos do ponto de vista da fisiopsicologia do criador perceberemos realmente que a arte é este tornarperfeito, idealizar, violentar as coisas de forma a destacar nelas determinadas perfeições e fazer surgir o sentimento de que elas são belas. Esse ponto de vista é, ao mesmo tempo, o ponto de vista do apaixonado e da sua embriaguez - um ponto de vista no qual o próprio desejar é já o mais intenso dos prazeres porque, ao projectar no objecto-amado todas as perfeições e ao antecipar a felicidade que estas prometem, permite àquele que assim deseja desfrutar de si mesmo como perfeição.

As notas póstumas sublinham a natureza eminentemente sexual desta embriaguez, no fundo o facto de a arte e o amour-passion serem espiritualizações da pulsão sexual. Eis dois exemplos:

[...] os artistas, quando são bons, têm uma disposição forte (também de corpo), excessiva, são animais de força, sensuais; sem um sobreaquecimento do sistema sexual um Rafael é impensável... [...] 
os artistas não devem ver as coisas como elas são, mas de forma mais cheia, mais simples, mais forte: para tal, têm de ter no corpo uma forma de eterna juventude e primavera, uma forma de embriaguez habitual. (KSA 13. 293, 14[117])

[...] para a génese da arte. Aquele tornar-perfeito, ver-como-perfeito, que é próprio de um sistema cerebral sobrecarregado de forças sexuais (a noite passada com a amada, as mais pequenas casualidades transfiguradas, a vida uma sucessão de coisas sublimes, 'a infelicidade dos amantes infelizes considerada como a coisa mais importante de todas'): por outro lado, tudo o que é perfeito e belo como lembrança inconsciente desse estado de paixão e do seu modo de ver - cada perfeição, toda a beleza das coisas evoca por contiguity a felicidade afrodisíaca. Fisiologicamente: o instinto criador do artista e a distribuição do sémen pelo seu sangue... O anseio por arte e beleza é um anseio indirecto pelos êxtases da pulsão sexual, que esta comunica ao cérebro. O mundo tornado perfeito, através do 'amor'... (KSA 12. 325-326, 8[1])

No "Crepúsculo dos Ídolos”, esta relação entre a sexualidade e a arte é tornada explícita de diversas formas. Uma delas é a reformulação da oposição "Stendhal contra Kant" como uma oposição entre Platão e Schopenhauer. Nesta oposição, Platão está do lado de Nietzsche e Stendhal - pois, ao contrário de Schopenhauer (e de Kant), concebe a beleza como o objecto de eros. Nos passos a que me refiro (CI Incursões 21-23), Nietzsche começa por criticar Schopenhauer por ter usado todas as "contra-instâncias" da desvalorização niilista da vida para defender justamente esta desvalorização (CI Incursões 21). Entre essas "contra-instâncias" (ou entre "as grandes auto-afirmações da 'vontade de viver', as formas de exuberância da vida"), conta-se a beleza, que Schopenhauer interpretou como uma "ponte" para a negação da vida e da vontade, como uma possibilidade de salvação ou redenção "do "foco da vontade', da sexualidade - na beleza, ele vê a pulsão reprodutora negada..." (CI Incursões 22). Tudo na natureza contradiz esta tese: na natureza, a sexualidade e a beleza são inseparáveis. Mas também Platão contradiz essa tese, nomeadamente ao defender que só há beleza quando há eros e que toda a beleza é, portanto, "um estímulo à procriação" (CI Incursões 22) ${ }^{4}$ A própria filosofia, segundo Platão, é no fundo um "concurso erótico" (CI Incursões 23). Uma das falhas da modernidade é a incapacidade de perceber este conceito de eros e a ligação entre a beleza e fenómenos como a procriação, a reprodução ou a gravidez. É por isso que os pensadores modernos, como Kant ou Schopenhauer, mas também os poetas modernos, como Goethe, não podem perceber o sentido mais profundo da religiosidade grega, que via o deus Dioniso como sendo "o símbolo sexual" e interpretava, não só a embriaguez

4 Nietzsche refere-se aqui ao "Banquete" de Platão e à famosa definição de eros não apenas como um desejo e uma atracção pelo belo, mas como um desejo de procriar no belo ( 206b). 
dionisíaca, mas também a própria vida à luz dos "mistérios da sexualidade" (CI Antigos 4). ${ }^{5}$

Ao promover esta espécie de regresso ao eros platónico e à embriaguez dionisíaca, Nietzsche mostra a que ponto é radical a sua intenção de romper não só com a estética schopenhaueriana, mas também com a estética kantiana. Por ter pensado o belo apenas "a partir do ponto de vista do "espectador" e por não ter podido reconhecer na experiência do espectador "uma experiência pessoal grande, um facto pessoal grande, uma enorme quantidade de vivências, de desejos, de surpresas, de encantamentos singulares e intensos, no plano do belo" (GM III 6), Kant fez do juízo estético o cerne da experiência estética e interpretou esse juízo como sendo fundamentalmente um juízo crítico, um juízo dotado da imparcialidade, impessoalidade e universalidade típicas da avaliação crítica e da perspectiva científica: "Kant pensava que estava a conceder uma honra à arte ao destacar e colocar em primeiro plano como predicados do belo aqueles predicados que são a honra do conhecimento: a impessoalidade e a validade universal" (GM III 6).

Para Nietzsche, pelo contrário, não só a experiência estética tem o carácter profundamente pessoal de um "amor-paixão", como radica na mais básica das pulsões e intensifica (em vez de suprimir) o mais básico dos afectos.

Mas não devemos dar razão a Kant? Não é o gosto que está em causa na experiência estética, e não devemos entender o gosto estético como a faculdade que nos permite fazer uma avaliação ou apreciação (Beurteilung) do belo, do feio e do sublime? Como negar que essa apreciação só possa ser expressa e comunicada num juízo? E, sobretudo, como negar que, no que respeita à arte, o valor deste juízo dependerá sempre do seu grau de espírito crítico, portanto do seu grau de imparcialidade, impessoalidade e universalidade? Se uma pessoa nos comunica apenas a sua reacção afectiva a uma obra de arte, se nos fala apenas da forma como esta a afectou pessoalmente ou se se refere à sua "beleza" como um efeito emocional imediato, não temos qualquer motivo para valorizar o seu juízo como juízo estético. O seu juízo estará ao mesmo nível de outros juízos em que exprimimos um agrado ou desagrado sensorial, por exemplo em relação ao sabor de um alimento ou ao cheiro de um perfume. Não esperamos de um juízo estético que ele seja um veredicto definitivo formulado com conceitos cientificamente verificáveis, mas esperamos, pelo menos, que ele seja uma crítica (inteiramente positiva, inteiramente negativa ou mista) que possa pretender ser comunicada a outrem e aceite por outrem - e que 
portanto não assente numa emoção apenas pessoal, pois esta é incomunicável por definição. Dizer que "o anseio por arte e beleza é um anseio indirecto pelos êxtases da pulsão sexual, que esta comunica ao cérebro", não é, ao invés, a forma mais grosseira e redutora de entender a experiência estética? Fazer equivaler a experiência estética à experiência do amor-paixão não elimina a dimensão crítica da experiência estética, de tal forma que o efeito da obra de arte passa a ser apenas algo que o espectador ou sente ou não sente? Devemos, de facto, envolver o eros platónico na experiência estética ou é preferível que preservemos a concepção kantiana do juízo estético como uma avaliação crítica? $^{6}$

O espólio de Nietzsche contém muitas notas com base nas quais se poderia reconstruir uma teoria do juízo estético alternativa à de Kant, e talvez se possa dizer que essa teoria está pressuposta em alguns passos cruciais da obra publicada. Vejamos em que consiste esta teoria e de que modo ela pode ajudar a esclarecer a oposição "Stendhal contra Kant".

\title{
II
}

Nietzsche concorda com Kant em que os nossos juízos estéticos são juízos de gosto. Mas, por outro lado, introduz a ideia de que: a) há juízos instintivos e devemos distingui-los dos juízos intelectuais; b) os juízos de gosto são primariamente instintivos; e c) quando os juízos de gosto se tornam intelectuais, dependem ainda (ou são contínuos com) juízos instintivos. Numa nota póstuma de 1887, por exemplo, Nietzsche diz o seguinte:

\begin{abstract}
Aesthetica. Sobre a génese do belo e do feio. Aquilo que nos repugna instintivamente, esteticamente, é o que se comprovou ser prejudicial, perigoso, digno de desconfiança no curso da mais longa experiência do ser humano: o instinto estético (por exemplo, no asco) que subitamente se exprime contém um juizo. Nessa medida o belo pertence à categoria geral dos valores biológicos do útil, benéfico, intensificador da vida: o que nos dá o sentimento do belo é uma multiplicidade de estímulos que, à distância, nos lembram de, e provocam associações com, coisas e estados úteis [...]. (KSA 12. $554,10[167])$
\end{abstract}

O sentimento de que algo é belo deriva, portanto, do instinto, mas tem a forma de um juízo. Podemos chamar-lhe, de facto, um "juízo instintivo" (Instinkt-Urtheil, KSA 12. 554, 10[167]). Numa nota de 1881, Nietzsche explica o que entende por esta ligação entre instinto, juízo e gosto: "Falo 
de instinto quando um qualquer juízo (ou o gosto no seu nível mais baixo) é incorporado, de tal forma que ele agora se estimula espontaneamente a si próprio e já não precisa de esperar por outros estímulos" (KSA 9. 505, 11[164]).

Os instintos são o produto "da mais longa experiência" da espécie humana, são o que a espécie "incorporou" na sua evolução ao longo do tempo. Alguns instintos são "automatismos" que resultam de experiências pessoais, mas mesmo esses devem ser vistos como desenvolvimentos de pulsões, afectos, sensações e memórias que se foram formando no curso do tempo-profundo da evolução da espécie. ${ }^{7}$ Os instintos "já não precisam de esperar por estímulos" porque são, no fundo, pulsões que se tornaram permanentemente activas, que constantemente procuram e encontram satisfação em estímulos e, portanto, se estimulam a si próprias. E a razão por que os instintos têm a forma de juízos é que, nesta sua permanente actividade, dizem "sim" e "não" - são afirmações e negações: avaliam umas coisas como "prejudiciais, perigosas, dignas de desconfiança" e outras como "úteis, benéficas, intensificadoras da vida". Dito de outro modo, os instintos são juízos porque os afectos e os sentimentos que necessariamente acompanham a sua actividade afirmam ou negam. Por exemplo: “[...] a dor [é] um juízo (um juízo negativo) na sua forma mais tosca[,] o prazer é uma afirmação" (KSA 12. 256, 7[3]). Quer isto dizer que os instintos são juízos porque criam valores, modificam outros valores, funcionam como avaliações ou apreciações, tais como " $x$ é belo" ou " $x$ é feio". Assim, o gosto "no seu nível mais baixo" não é senão um conjunto de juízos instintivos que discriminam e avaliam segundo o valor "belo" (ou "o que é útil, benéfico, intensificador da vida") e o valor "feio" (ou "o que é prejudicial, perigoso, digno de desconfiança").

Porém, como é óbvio, os juízos instintivos não são o único tipo de juízo que existe. Na mesma nota de 1887 acima citada, Nietzsche estabelece o seguinte contraste entre juízos instintivos e juízos intelectuais:

Todos os juízos instintivos têm vistas curtas no que respeita à cadeia de consequências: aconselham sobre o que fazer primeiro. O entendimento é essencialmente um aparelho de inibição contra a reacção imediata ao juízo instintivo: ele retarda, continua a reflectir, vê a cadeia de consequências até mais longe e durante mais tempo.

Os juízos de beleza e fealdade têm vistas curtas - têm sempre o entendimento contra si -: mas são persuasivos no grau mais elevado: apelam aos nossos instintos

7 Cf., por exemplo, KSA 11. 175, 26[94], KSA 13. 329, 14[144], AC 57. Sobre este conceito de instinto, cf. Lupo, 2006, p. 75f.; sobre a distinção entre juízos instintivos e juízos intelectuais, cf. Lupo, 2012, pp. 179195. 
no ponto em que eles decidem mais depressa e dizem o seu sim e não, antes de o entendimento poder usar da palavra. (KSA 12. 554-555, 10[167])

Porque os instintos são "automatismos", ajuízam muito depressa e fazem-nos agir antes de avaliarmos de forma consciente e racional as suas avaliações; o "entendimento" (ou o "intelecto", no fundo a razão consciente) é precisamente um "aparelho de inibição" que nos permite distanciarmo-nos do que percepcionamos, reavaliarmos as nossas avaliações mais imediatas e ponderarmos as consequências das nossas acções. Os juízos instintivos são, na verdade, algo que sempre já aconteceu quando tomamos consciência deles, ao passo que os juízos intelectuais (ou "sapientes") são processos conscientes, que levam o seu tempo. Dado que têm esta natureza, chegam muitas vezes tarde demais, isto é, já depois de termos agido em conformidade com um "sim" ou um "não" instintivo. Mas não deixam por isso de ser os nossos melhores juízos: a sua lentidão torna-os superiores do ponto de vista cognitivo.

O passo que acabámos de citar sugere também que todos os juízos instintivos são juízos estéticos (i.e. juízos de gosto), e todos os juízos estéticos são juízos instintivos. Os nossos juízos estéticos são sempre os que têm vistas mais curtas, os nossos piores juízos? Há certamente aqui um mistério. Primeiro porque Nietzsche apresenta muitas vezes os juízos instintivos como aqueles que, por terem atrás de si uma longa história na evolução da espécie, garantem o funcionamento normal e saudável do organismo, e os juízos intelectuais, racionais e conscientes como juízos superficiais, que tendem a ser inibitivos a ponto de porem em risco o próprio funcionamento do organismo. ${ }^{8}$ Depois porque na obra de Nietzsche abundam os juízos estéticos intelectuais, longos raciocínios e elaborações críticas sobre múltiplas obras de arte e os artistas que as criaram. É evidente que há juízos estéticos que são intelectuais, juízos que resultam do uso desse "aparelho de inibição" que trava as avaliações mais imediatas e que as reavalia. Se o gosto "no seu nível mais baixo" é instintivo, isso não exclui de forma alguma que o gosto seja também algo que se educa, algo que se transforma com a reflexão e a acumulação de experiências diferentes - algo sobre o qual o entendimento tem, portanto, influência. Por que razão sugere então Nietzsche que todos os juízos estéticos são instintivos?

Podemos, talvez, começar a tentar responder a esta pergunta se considerarmos o facto de, nos passos aqui em causa, Nietzsche procurar dar às palavras "belo" e "feio" o sentido mais lato possível. A identificação entre juízos instintivos e juízos estéticos pretende fazer do "belo" e do "feio" os 
valores mais básicos da nossa vida pulsional, e pretende fazer do gosto a nossa forma mais básica de nos relacionarmos connosco mesmos e com o mundo. Numa outra nota de 1881, Nietzsche escreve o seguinte: "Os juízos estéticos (o gosto, mal-estar, asco etc.) constituem a base das tábuas de valor [ou 'tábuas de bens', Gütertafel]. Estas, por sua vez, são a base dos juízos morais" (KSA 9. 471, 11[78]). ${ }^{9}$

$\mathrm{O}$ que encontramos aqui é novamente a ideia de um continuum, que determina que estados psicológicos mais complexos sejam superfícies, espelhos, instrumentos, signos, sintomas de outros estados psicológicos mais simples, sendo os primeiros, em regra, estados instintivos e inconscientes e os segundos, estados conscientes que envolvem conceptualização e simbolização. Os juízos estéticos, no seu nível mais elementar, são reacções imediatas - reacções de mal-estar, asco, mas também de prazer, agrado, etc.. Podemos dizer também que são o mesmo que manifestações de um gosto ainda meramente instintivo, ou afirmações e negações que, de forma imediata e instintiva, avaliam umas coisas como "prejudiciais, perigosas, dignas de desconfiança" e outras como "úteis, benéficas, intensificadoras da vida". Todas as tábuas de valor são desenvolvimentos destas avaliações mais básicas, instintivas. Portanto, mesmo os valores mais complexos e supostamente mais elevados - os valores morais - são ainda desenvolvimentos de avaliações instintivas sobre o que é, no sentido mais lato do termo, "belo" ou "feio". Ou, dito de outro modo, os valores morais são superfícies, espelhos, instrumentos, signos, sintomas de valores estéticos. Quando se apresentam como algo válido "em si”, continuam a ser, na verdade, uma questão de gosto, simplesmente de um gosto mascarado por conceptualizações e simbolizações cuja reificação gera a ilusão de um "em si", a ilusão de uma absoluta independência em relação a avaliações estéticas instintivas.

Isto permite concluir já que não se trata, para Nietzsche, de reduzir o estético ao instintivo, mas de defender que toda a complexificação, todo o desenvolvimento conceptual e simbólico do instintivo é sempre ainda estético. A sua ideia não é que não haja juízos estéticos intelectuais, mas sim que estes juízos são desenvolvimentos conceptuais e simbólicos de outros juízos mais básicos. Tanto assim é que até os juízos morais são também desenvolvimentos destes juízos mais básicos (e, neste sentido, os juízos estéticos intelectuais são como os juízos morais). 
Assim se esclarece também por que razão Nietzsche parece fazer avaliações contraditórias do valor dos juízos instintivos e dos juízos intelectuais. Os juízos intelectuais são, no fundo, juízos instintivos que se tornaram intelectuais, e dependem sempre ainda (ou são sempre ainda contínuos com) dos juízos instintivos a partir dos quais se desenvolveram. Assim, são meramente inibitivos e chegam a pôr em risco o funcionamento normal do organismo apenas quando as conceptualizações neles envolvidas entram em tensão com os juízos instintivos a partir dos quais se desenvolveram - ou seja, quando há uma espécie de curto-circuito no continuum e isto os impede de serem "incorporados" (GC 11). Em contrapartida, a sua superioridade cognitiva é aproveitada, e não desperdiçada, quando a sua acção inibidora logra integrar-se na acção dos juízos instintivos pré-existentes - i.e. quando ela transforma a constelação de instintos que a sustenta e, por fim, o seu conteúdo se torna ele próprio instintivo e inconsciente (ou é "incorporado").

Isto não significa, porém, que seja benéfica a incorporação de todos os juízos intelectuais. Os mais básicos de entre os juízos instintivos, aqueles que fazem o gosto "no seu nível mais baixo", resultam da longa evolução da espécie e são, por isso, formas de protecção, preservação, afirmação da espécie. Correspondem àquilo a que Schopenhauer chama a "vontade de viver", cujo "foco", como sabemos, é a sexualidade, o instinto reprodutor. Ora, sendo assim, os juízos intelectuais que entram em curto-circuito com esses juízos instintivos mais básicos são juízos que põem em risco a "vontade de viver" - criam o tipo de conflito e contradição interna que promove a negação da vida, e a que Nietzsche chama décadence. Aqui o risco não está tanto no efeito perturbador da sua não-incorporação quanto na sua incorporação. É esta incorporação que cria o tipo de organização instintiva, pulsional e afectiva a que se pode chamar decadente, negadora, auto-lesiva - o tipo que determina que um ser humano possa escolher e preferir aquilo que o prejudica enquanto espécime e enquanto indivíduo (AC 6).

\section{III}

É neste contexto que Nietzsche interpreta os juízos estéticos à luz da hipótese da vontade de poder. Por exemplo, numa das notas póstumas acima citadas, Nietzsche explica o "sentimento do belo", simplesmente, como sinónimo de um "aumento do sentimento de poder" (KSA 12. 554, 10[167]), e na nota imediatamente seguinte do mesmo caderno escreve que "se ou onde $<$ o> juízo ‘belo’ é aplicado" é apenas "uma questão de força (de um indivíduo ou de um povo)" - pois “o sentimento de poder aplica o juízo ‘belo’ também a 
coisas e estados que o instinto da impotência desvalorizaria como sendo apenas merecedoras de ódio, como "feias"'. Para esclarecer esta afirmação, Nietzsche acrescenta um parêntesis em que diz que "isto é belo" é uma afirmação" (KSA 12. 555-556, 10[168]). Quando, no "Crepúsculo dos Ídolos”, explica todos os sentimentos estéticos através do conceito de embriaguez (Rausch) diz, como vimos, que o essencial nesta embriaguez é "o sentimento de intensificação da força e do preenchimento" (CI Incursões 8), ou seja, precisamente o crescimento do sentimento de poder. O juízo estético "isto é belo" exprime, em suma, um sentimento de embriaguez que é sinónimo de um crescimento do sentimento de poder - sinónimo de uma afirmação ou satisfação da vontade de poder dos instintos mais básicos do organismo; o juízo "isto é feio" exprime um sentimento depressivo que é sinónimo de um sentimento de impotência - sinónimo de uma negação ou insatisfação da vontade de poder daqueles instintos mais básicos, em particular do instinto sexual.

É precisamente esta concepção dos juízos estéticos que está em causa num dos passos mais importantes sobre todo este tema, o aforismo 19 das "Incursões de um extemporâneo" no "Crepúsculo dos Ídolos":

Belo e feio. - Nada é mais condicionado, digamos mais limitado, do que o nosso sentimento do belo. Quem o quisesse pensar desligado do prazer do ser humano no ser humano perderia imediatamente o chão sob os seus pés. O 'belo em si' é uma mera palavra, nem sequer chega a ser um conceito. No belo, o ser humano põe-se a si próprio como medida da perfeição; em casos selectos, adora-se a si próprio. Uma espécie não pode senão fazer isto: dizer 'sim' apenas a si própria. O seu instinto mais básico, o instinto de auto-preservação e auto-propagação, irradia ainda em tais sublimidades. O ser humano acredita que o mundo é sobreabundante em beleza, mas esquece-se de que é ele a causa disso. Foi apenas ele quem o dotou de beleza, mas, ah!, só de uma beleza humana, demasiado humana... No fundo, o ser humano vê-se espelhado nas coisas, toma por belo tudo aquilo que lhe devolve a sua imagem: o juízo ‘belo’ é a sua vaidade da espécie... (CI Incursões 19)

Não existe o belo "em si", o belo, como já Kant havia demonstrado, é "subjectivo". Para Nietzsche, esta sua subjectividade significa, contudo, que o belo é relativo à espécie, só "existe" na medida em que o instinto mais básico da espécie - o instinto sexual como instinto de auto-preservação e auto-propagação da espécie - o faz aparecer nas coisas. É esse instinto que violenta as coisas, que idealiza, que faz aparecer nas coisas (e primariamente em outros espécimes) perfeições que geram o sentimento de que algo é belo. Este poder de idealizar e fazer aparecer perfeições é o que, por fim, aparece espelhado nas coisas que se sente serem belas, e isso quer dizer que tais perfeições são reflexos, espelhos, imagens do sentimento da nossa perfeição, 
da nossa beleza, do poder do instinto mais básico da nossa espécie. ${ }^{10}$ Portanto, a subjectividade do belo significa que ele é um antropomorfismo, uma projecção antropomórfica - a "vaidade da espécie". E, se é assim, os juízos estéticos têm de facto vistas curtas e não há nada "mais limitado do que o nosso sentimento do belo": as avaliações que nos dizem que algo é belo (ou feio) nunca nos levam além de nós mesmos enquanto espécimes de uma dada espécie, nunca são mais do que espelhamentos ou reflexos do nosso sentimento de poder (ou de impotência).

Mas é neste ponto-chave que devemos ter a máxima cautela interpretativa. Se o belo é um reflexo do nosso sentimento de poder enquanto espécimes, então o sentimento do belo é o sentimento afirmativo por excelência - é a própria afirmação da vida, pelo menos enquanto afirmação da vida da espécie. A tese de que o juízo e o sentimento do belo são apenas a "vaidade da espécie" parece, à primeira vista, um simples sarcasmo, mas ela identifica a fonte de todas as formas de afirmação da vida; e a tese de que o belo é apenas uma idealização ou uma projecção antropomórfica parece reduzir o belo a uma ilusão, mas também nela se trata de identificar a actividade criativa que torna possíveis todas as formas de afirmação da vida. Mas não seria maximamente contraditório que Nietzsche quisesse fazer pouco da afirmação da vida e dos seus pressupostos?

$\mathrm{Na}$ continuação do aforismo 19 das "Incursões de um extemporâneo", Nietzsche sugere justamente que o aforismo esconde uma espécie de segredo. Um céptico, explica Nietzsche, diria simplesmente que o belo é de facto apenas um antropomorfismo e uma ilusão. Mas imaginemos um "juiz do gosto" mais elevado: por exemplo, o deus Dioniso num diálogo com Ariane. Se Dioniso (que é, por excelência, o deus da afirmação da vida) ouvisse dizer que o belo é apenas um ilusão, puxaria as orelhas a Ariane (que representa aqui o ser humano) e diria: "As tuas orelhas têm uma certa graça, Ariane: por que não são maiores?" (CI Incursões 19). Precisamos, portanto, de ouvir melhor o que Nietzsche quer dizer.

\section{IV}

Pelo menos à superfície, a posição do céptico no aforismo 19 das "Incursões de um extemporâneo" lembra mais um aspecto da filosofia de Schopenhauer - e faz pensar numa das mais estranhas contradições (ou, 
pelo menos, aparentes contradições) da sua obra. Schopenhauer defende, por um lado, como vimos, que o belo só pode ser o objecto de uma contemplação desinteressada, mas, por outro, defende que o belo é algo que certos espécimes vêem noutros espécimes porque o seu instinto sexual os programou para terem este comportamento. O belo faz parte da ilusão e do delírio que a espécie plantou nos indivíduos que a constituem para os convencer a reproduzirem-se, i.e. a assegurarem a preservação da espécie. A "vontade de viver" é a vontade da espécie, e o belo é o engodo que a espécie utiliza para que os espécimes satisfaçam essa vontade (e não a sua própria vontade ou o seu interesse enquanto indivíduos). ${ }^{11}$ Há, de facto, aqui uma pura contradição, ou Schopenhauer distingue dois sentidos de belo? Num primeiro sentido, o belo seria, por assim dizer, um evento natural - uma projecção antropomórfica e uma ilusão subjectiva induzida pelo instinto sexual -, mas, no seu sentido propriamente estético, seria o efeito apenas cognitivo ou espiritual da contemplação da pura forma dos objectos. Esta contemplação seria precisamente uma libertação da suposta tirania do instinto sexual.

Nietzsche não aceita que esta libertação exista. É essa a sua objecção à ideia de contemplação desinteressada. Mesmo a contemplação estética aparentemente mais desinteressada é ainda um "anseio indirecto pelos êxtases da pulsão sexual" (KSA 12. 325-326, 8[1]). Mas significa isso que Nietzsche não reconhece qualquer valor à passagem de um anseio directo pelos êxtases da pulsão sexual a um anseio indirecto? A sua tese é que estamos para sempre presos à "vaidade da espécie" e não há qualquer possibilidade de nos libertarmos das nossas avaliações mais básicas? A sua ideia é a de que ou afirmamos a vida da forma mais instintiva e animal, ou então negamos a vida porque determinados juízos intelectuais perturbam a saúde animal do nosso organismo e nos tornam decadentes?

Temos de responder "não" a todas estas perguntas se nos recordarmos do que vimos acima sobre o fenómeno da espiritualização e da transformação do instinto sexual em amor-paixão. Dissemos que Nietzsche entende a espiritualização dos instintos ou das pulsões como um processo de interiorização que as intensifica. Esta espiritualização distingue-se da contemplação desinteressada porque não nos des-afecta. Pelo contrário, potencia os afectos, gera embriaguez. Talvez não haja na obra de Nietzsche uma imagem mais clara do significado desta espiritualização das pulsões do

11 Cf. WWV II § 44 (o parágrado onde Schopenhauer expõe a sua famosa "metafísica do amor sexual"); cf. também a WWV I Anhang, 628-629, onde Schopenhauer diz concordar com a tese kantiana de que o belo é "subjectivo". 
que a imagem do "pathos da distância" no aforismo 257 de "Para além do Bem e do Mal". Este pathos designa, em primeiro lugar, a psicologia de uma das partes de um dado tipo de relação social, nomeadamente a psicologia do aristocrata que olha de cima para os seus inferiores na escala social, crê que esta escala social reflecte uma verdadeira diferença de valor e, por isso, sente uma enorme distância entre si e todos aqueles que considera seus "súbditos e instrumentos" (BM 257). O aforismo diz que este pathos social é a précondição de um "outro pathos mais misterioso", um pathos da distância apenas interior - que não tem, portanto, esse cariz social e ocorre apenas "dentro da própria alma" (BM 257). Aquele pathos social é sobretudo uma imagem deste outro pathos apenas interior, e podemos abstrair aqui da discussão sobre se um é realmente a pré-condição do outro. A ideia fundamental que nos importa reter é a de que o desenvolvimento do espírito, a espiritualização ou sublimação das pulsões e dos afectos, é um processo que gera um pathos de distância semelhante àquele que o aristocrata sente em relação aos seus inferiores na escala social. Nietzsche descreve assim este pathos de distância interior:

[...] um anseio que exige um alargamento sempre novo da distância dentro da própria alma, o desenvolvimento de estados sempre mais elevados, mais raros, mais longínquos, mais abrangentes, mais amplos, em suma: precisamente a elevação do tipo 'ser humano', a contínua 'auto-superação do ser humano', para usar uma expressão moral num sentido supra-moral. (BM 257)

A espécie humana tem esta estranha natureza. Há muito que a sua evolução passou a ser fundamentalmente a evolução do seu espírito. Como Nietzsche bem sabia, "evolução" é um termo neutro, que não implica em si mesmo nem progresso nem elevação. Uma espécie pode evoluir no sentido da sua expansão, mas também pode evoluir no sentido da sua decadência. No caso da espécie humana, as suas possibilidades de expansão ou decadência estão no espírito - a elevação do tipo 'ser humano', a contínua 'auto-superação do ser humano' é uma questão do espírito, do alargamento ou do estreitamento da distância dentro da própria alma. Fisiologicamente, a evolução da espécie é sempre a evolução das suas pulsões, afectos e instintos, mas esta evolução depende em grande medida das conceptualizações e simbolizações que, por um lado, emergem dessas pulsões, afectos e instintos, por outro, os modificam, os reconfiguram, os atrofiam ou libertam. O tipo de consciência que nos caracteriza - um tipo de consciência que envolve conceitos, palavras e outros "signos de comunicação" (GC 354, BM 268) - distingue-nos, de facto, dos outros animais e, em última análise, distingue-nos deles porque cria distância, isto é: porque os conceitos, as palavras e os signos de comunicação que a 
constituem tornam possível uma constante reavaliação das nossas avaliações mais imediatas.

Sendo certo que, para Nietzsche, uma tal reavaliação nunca é afectiva ou pulsionalmente neutra (nunca é "desinteressada"), não é menos certo que ela ocorre e que depende em parte da consciência sapiente. A espiritualização das pulsões, dos afectos e dos instintos consiste nesta sua modificação por meio da consciência - uma modificação que gera um pathos de distância porque implica um processo de reavaliação de outras avaliações e, portanto, distância em relação a estas outras avaliações. Quando este processo gera reavaliações que entram em curto-circuito com os instintos mais básicos e dão origem a comportamentos auto-lesivos e negadores da vida, ele é um processo de décadence; quando gera reavaliações que, pelo contrário, expandem o sentimento de poder e intensificam a afirmação da vida, é um processo de elevação e auto-superação do ser humano.

Consideremos o caso do amor-paixão. Nietzsche diz expressamente que o amor-paixão é uma espiritualização da pulsão sexual (KSA 12. 537, 10[144]). Nesta espiritualização, o objecto em que a pulsão se fixa é "interiorizado": a imaginação põe em marcha conceptualizações e simbolizações que geram uma multiplicidade de sentimentos, volições e pensamentos conscientes nos quais esse objecto (por exemplo, a mulher amada) aparece como sendo muito mais do que apenas um objecto que pode satisfazer aquele que seria em princípio (ou que seria inicialmente) o alvo ou a meta da pulsão (i.e. o acto sexual). Este alvo (Ziel) é, portanto, radicalmente modificado pelo processo de interiorização - torna-se mais complexo, e também mais difuso: em vez do simples acto sexual, ele é agora a felicidade prometida pelas perfeições que se cristalizam na imagem que o apaixonado faz da mulher amada. Obviamente, este é um processo de interiorização e espiritualização porque tudo se passa "dentro da própria alma", no "espírito", no desenvolvimento de determinadas imagens, conceitos, palavras, sentimentos, volições e pensamentos. Este desenvolvimento escapa ao controlo da consciência, mas não é possível sem ela, e a imaginação tem aqui um papel crucial, mas apenas enquanto um tipo de imaginação que, por um lado, gera palavras e conceitos, por outro é constantemente estimulada e modificada por palavras e conceitos. Sem palavras e conceitos - sem a forma de consciência humana - a imaginação não teria o poder transformador que adquire na construção de um amor-paixão. Mas o que isso verdadeiramente significa é que sem essa forma de consciência não pode haver a reavaliação do valor do alvo inicialmente visado pela pulsão sexual, não pode haver "o desenvolvimento de estados sempre mais elevados, mais raros, mais longínquos, mais abrangentes, mais amplos”. Estes estados 
são um pathos interior de distância, e de uma distância que, de facto, não desafecta, mas, pelo contrário, intensifica o desejo: "A magia e o mais poderoso efeito das mulheres é, para falar na linguagem dos filósofos, um efeito à distância, uma actio in distans" (GC 60).

Se olharmos agora para a arte sob a óptica do artista, podemos perceber finalmente o sentido e as implicações da analogia entre o amor-paixão e a criação artística. A tese do "Crepúsculo dos Ídolos" e das notas póstumas que citámos é a de que o belo é sempre a vaidade da espécie e, no caso da arte, o belo artístico é criado num estado de embriaguez que pressupõe um sobreaquecimento do sistema sexual do artista. Mas isto não reduz a criação artística a uma mera manifestação do poder do instinto sexual da espécie. A idealização que resulta da criação artística (o "ter de tornar perfeito", a projecção antropomórfica de perfeições) é um processo de espiritualização semelhante ao amor-paixão. Tal como o amor-paixão pressupõe a pulsão sexual, mas não se reduz a ela porque é a sua espiritualização, assim também a criação artística pressupõe a vaidade da espécie e o sobreaquecimento do sistema sexual do artista, mas não se reduz a este sobreaquecimento porque é a sua espiritualização. Também a arte depende de um pathos da distância e do "desenvolvimento de estados sempre mais elevados, mais raros, mais longínquos, mais abrangentes, mais amplos". O horizonte em que ocorre o desenvolvimento destes estados é sempre o da vaidade da espécie - o do espelhamento do poder da espécie -, mas esse horizonte é alargado, ampliado à medida que é criada distância "dentro da própria alma".

O que caracteriza a arte é, portanto, a capacidade (umas vezes actualizada, outras não) de reavaliar e, assim, de ampliar o conceito de belo, a concepção que a espécie faz (por meio dos seus espécimes, os indivíduos) daquilo que é "útil, benéfico, intensificador da vida" e daquilo que é "prejudicial, perigoso, digno de desconfiança". As suas vistas são curtas porque nunca vão para lá do horizonte dos antropomorfismos em que se joga o ser "belo" ou "feio" para a espécie - ou em que se joga a vaidade da espécie -, mas, em contrapartida, o seu proprium é justamente o alargamento dessas vistas, a permanente reavaliação do que é "útil, benéfico, intensificador da vida" e do que é "prejudicial, perigoso, digno de desconfiança". A arte "não se limita a imaginar, ela modifica os valores" (KSA 13. 299, 14[120]) -, transforma-os num processo de interiorização, espiritualização e alargamento da perspectiva que é já, por si, uma "elevação" e "auto-superação do ser humano" (do "animal que permanece indeterminado", BM 62). O instinto sexual é um instinto que afirma a vida afirmando a preservação e propagação da espécie - mas a sua espiritualização na arte afirma a vida mediante um alargamento 
e reavaliação de valores que recria a espécie e a eleva a um novo patamar de desenvolvimento.

É esta, em última análise, a grande lição de Stendhal contra a definição kantiana do belo como aquilo que agrada desinteressadamente - contra o princípio da pura autonomia da arte, da "arte pela arte". A arte satisfaz um interesse: enquanto espiritualização da pulsão sexual e permanente recriação de uma "promessa de felicidade", ela satisfaz o interesse da espécie na afirmação da vida - mas precisamente enquanto espiritualização, enquanto embriaguez, enquanto análogo do amor-paixão, enquanto eros espiritual, ela satisfaz esse interesse de um modo que modifica, expande, amplia e eleva a própria espécie e o seu interesse. Sem esta plasticidade que resulta da sua natureza espiritual, ela nunca poderia ter a complexidade que lhe permite ser um "contra-movimento" 12 capaz de contribuir para a "luta contra o niilismo" (KSA 12.202, 5[50], KSA 12. 306, 7[31]). Ou, nos termos da "Genealogia": sem tal plasticidade, a arte nunca poderia ter a complexidade que permite pensá-la como sendo movida por uma "vontade" contrária à do "ideal ascético", uma vontade "na qual se exprime o ideal contrário [ao ideal ascético]" (GM III 25). Só esta complexidade a torna capaz de encontrar sempre novas formas e avaliações que respondem ao niilismo e à negação da vida.

Portanto, não há dúvida de que Nietzsche crê na possibilidade de nos libertarmos das nossas avaliações mais básicas e reconhece um enorme valor ao facto de, na arte, já não estar em causa um anseio directo pelos êxtases da pulsão sexual, mas apenas um anseio indirecto. Há uma terceira possibilidade entre a saúde do animal que afirma a vida mediante satisfação directa dos seus instintos e a decadência de um "animal doente" que intelectualiza e curtacircuita os seus instintos. Essa terceira possibilidade está na espiritualização dos instintos, em especial na sua espiritualização artística. Embora seja uma intensificação da pulsão sexual, a arte vai muito para lá da satisfação directa da pulsão sexual e tem, portanto, a plasticidade que lhe permite ser um contramovimento que combate o niilismo, essa patologia do desejo que é o cansaço e a náusea do ser humano em relação a si próprio.

\section{Referências}

LUPO, L. "Le Colombe dello Scettico, Riflessioni di Nietzsche sulla Coscienza negli anni 1880-1888”. Pisa: ETS, 2006. 
LUPO, L. "Drives, Instincts, Language, and Consciousness in Daybreak 119: 'Erleben und Erdichten'”. In: J. Constâncio; M. J. M. Branco (ed.). As the Spider Spins: Essays on Nietzsche's Critique and Use of Language. Berlin/Boston: Walter de Gruyter, 2012. pp. 179-195.

NEHAMAS, A. "Only a Promise of Happiness, The Place of Beauty in a World of Art". Princeton/Oxford: Princeton University Press, 2007.

PIPPIN, R. B. "Nietzsche, Psychology, \& First Philosophy". Chicago/London: The University of Chicago Press, 2010.

SCHOPENHAUER, A. "Die Welt als Wille und Vorstellung Erster Band". In: A. Schopenhauer. Sämtliche Werke, Zweiter Band. Ed. A. Hübscher. Wiesbaden: Brockhaus, 1946-1950. 7 vols. (Citado como WWV I).

SCHOPENHAUER, A. "Die Welt als Wille und Vorstellung Zweiter Band". In: A. Schopenhauer. Sämtliche Werke, Dritter Band. Ed. A. Hübscher. Wiesbaden: Brockhaus, 1946-1950. 7 vols. (Citado como WWV II).

STENDHAL, H.-M. B. (1822). "De l'amour". Paris: Gallimard, 1980. 